\title{
Effect of storage and anti-nutritional components in stored pelleted fish feed
}

\author{
Effiong Bartholomew Nyong ${ }^{1}$, Fakunle Janet Olubunmi ${ }^{2}$ \\ ${ }^{1}$ Department of Food Science and Technology, University of Uyo, Uyo, Nigeria \\ ${ }^{2}$ Department of Fisheries Technology, Federal College of Freshwater Fisheries Technology, New Bussa, Nigeria
}

\section{Email address:}

bartheffiong433@gmail.com (Effiong B. N.)

To cite this article:

Effiong Bartholomew Nyong, Fakunle Janet Olubunmi. Effect of Storage and Anti-Nutritional Components in Stored Pelleted Fish Feed. International Journal of Science, Technology and Society. Vol. 2, No. 6, 2014, pp. 186-189. doi: 10.11648/j.ijsts.20140206.14

\begin{abstract}
The effect of storage on the nutritional composition of pelleted fish feed as well as the anti-nutritional components was studied using two commercially formulated feeds: Coppens (exotic) and vital (local) feeds. Feed samples were purchased and monitored in storage at ambient temperature forth nightly for 6 weeks using standard procedures. Result obtained showed reduction in feed quality as the storage period increased with significant difference $(\mathrm{P}>0.05)$ in all nutrient components studied (moisture, protein, lipid, ash, crude fibre and nitrogen free extract).There was however no significant difference $(\mathrm{P}>0.05)$ between the nutritional components of feed samples during the storage period. Anti-nutritional components detected in feed samples were oxalate, phytate and tannins with phytate having the highest values in both feed samples.
\end{abstract}

Keywords: Fish Feed, Pellets, Storage, Nutrients, Temperature

\section{Introduction}

Prepared feeds for fish are perishable (Abowei and Tawari, 2011). They are also relatively fragile depending on the type of feed. The activities of insects, microorganisms and animals as well as improper handling, plus physical and chemical changes due to change in temperature and humidity pose serious problem of deterioration in stored fish feeds. Although, these causes are inter-related, the effect of microbial activity in stored feeds reduces nutritional value owing to the loss of dietary lipids, amino acids and vitamins by enzymatic digestion (Jones, 1987; Lim et al., 2008). It may also assist in the development of lipid ketonic rancidity and non-ketonic browning (Cockerel et al., 1971). In addition, Chow (1980) reported that mold infestation also produce poorer flavor and appearance making feeds lump and less palatable.

Feed processors attempt to formulate and manufacture aquaculture feeds to extend their shelf life and improve durability. However the degree to which aqua culturists can reduce wasted feed and realize its full purchase value is alternately dependent on how well the basic principles of storage and handling are understood and applied.

Microorganisms invade feeds and feed stuffs during storage causing deterioration, these include bacteria and fungi. Fungi contamination of fish feed have been reported to result in aflatoxicosis. Aflatoxins are chemicals produced by fungi like Aspergillus flavus and A. parasiticus (Russo and Yonong, 2006). Mold infested fish feed have been reported to impact negatively on the growth of Heterobranchus bidorsalis fish (Effiong and Alatise, 2009).

Aflatoxins present in fish have been known to be capable of having carcinogenic effects on human consumers of contaminated fish (Brown, 2007). The occurrence of these microbial strains in fish feeds have been reported to depend on the storage condition of the feed, particularly temperature (Nwabueze and Nwabueze, 2011).Poor storage conditions of feed will enhance microbial activity. Studies conducted to determine the effect of storage on the nutritional composition of pelleted fish feed are limited. Coppens and Vital feeds used in this experiment are exotic and local feeds respectively used commonly by farmers in aquaculture systems in Nigeria. Coppens feed is manufactured by Coppens International, Belgium, Netherland while Vital feed is manufactured by Grand Cereals Ltd., Jos, Nigeria.

This experiment was therefore conducted to determine the effect of storage on nutrient quality of feeds at ambient temperature; determine quality changes in different feed samples stored under the same conditions; and determine the anti- nutritional components in the pelleted fish feed samples in storage. 


\section{Materials and Methods}

One $\mathrm{kg}$ each of exotic (Coppens) and locally manufactured (Vital) feeds were purchased from a retail outlet in Ilorin, Nigeria with manufacturing and expiring dates noted in both feeds. The feed samples were 5 and 3 weeks old respectively from the day of manufacture at the time of purchase. They were packaged in air tight containers and sent for proximate and anti-nutritional analysis at the Agricultural Technology Research Laboratory, Federal University of Technology, Akure (FUTA) Nigeria. Analysis was conducted forth nightly for 6 weeks. The methods for analyses were the standard procedures of AOAC (1990). Moisture content was determined by oven- drying (at $105^{\circ} \mathrm{C}$ ) samples for 24 hours, ash by incineration of $2 \mathrm{~g}$ of each samples in a muffle furnace (Lenton Furnaces, England) at $600^{\circ} \mathrm{C}$ for 2 hours; protein was estimated as nitrogen content $(\mathrm{Nx6.25)}$ by the microkjeldahl method; crude fibre by acid-base digestion using $1.25 \% \mathrm{H}_{2} \mathrm{SO}_{4}(\mathrm{~W} / \mathrm{V})$ and $1.25 \% \mathrm{NaOH}(\mathrm{W} / \mathrm{V})$ solution, available nitrogen free extract was calculated by difference.

All proximate components were analyzed in triplicate and reported as means on percentage dry weight basis. Tannins, oxalate and phytate were determined as the anti-nutritional feed components using the method of Friedman and Shibko (1972).

For microbiological analysis, $1.0 \mathrm{~g}$ of feed sample was ground forth-nightly using pestle and mortar to prepare a 10fold serial dilution. Agar used for the culture and isolation of microorganisms was Potato Dextrose Agar. This was prepared using sterilized glassware according to manufacturer's instruction and autoclaved at $121^{\circ} \mathrm{C}$ for 15 minutes. It was allowed to cool to about $37^{\circ} \mathrm{C}$ before $1 \%$ streptomycin was added to prevent bacterial contamination (Nwachukwu, 1988).

A 48-hour- old culture of the isolates was subcultured and incubated at room temperature to produce pure cultures from which stock was prepared and stored. Mold isolates were characterized during sporulation on the basis of cultural and morphological characteristics as well as direct microscopic examination (Oloke et al., 1988).

Three replications were used to obtain average values and standard deviations while T- Test was used to compare the effect of storage on the nutrient contents in both samples of the experimental feed.

\section{Results and Discussion}

The result of the proximate composition of both feeds samples (Coppens) and (Vital) feeds stored for 6 weeks and monitored forth nightly is shown in Tables 1 and 2. Moisture was higher in Vital feeds (locally manufactured) than Coppens (exotic) and was significantly different $(\mathrm{P}<0.05)$. Most nutrients were also significantly different including protein and lipid over the storage period in both feed samples.

A decreasing trend in the nutritional content of the feed samples was observed generally in both feeds from week zero (initial) to week six. Bautisa et al; (1992) and Ramezanzadeh et al.; (1999) both reported that high temperature resulted in increase in both oxidative and hydrolytic rancidities with possible loss in quality in stored fish feeds. Studies by Hamilton (1989); Sandars (1989), Van den Berghe et al; (1990) and Ruiz et al; (2000) indicated that fats are intrinsically unstable when under temperature of about $30^{\circ} \mathrm{C}$. FAO (1987) reported that environmental factors such as moisture, relative humidity, temperature, light and oxygen cause deteriorative changes and losses in stored feed and feed stuff. High moisture levels in stored feed result in loss of quality due to growth of micro- organisms. The quality of fish feeds and the hygienic levels of the technological process employed during feed formulation determine the level of risk of microbial contamination aided by temperature (Nwabueze and Nwabueze, 2011).

The anti- nutritional components found in the feed samples over the period of six weeks are shown in Table 3. Francis et al; 2001 reported the presence of a wide range of antinutritional components in plants- derived fish feed components including phytate, oxalate and tannins stating that their presence is unlikely to affect fish growth performance especially if proper heat treatment is carried out during feed formulation process. Makkar, and Becker (1999a and 1999b) reported similar findings. Phytate content in both feeds were higher than those of oxalate and tannins and their concentrations increased with increase in the storage period. Their levels from the findings of this experiment were however within safe limit (FAO/IAEA, 2000).

Molds isolates identified from the experimental feed samples were Fusarium oxysporium, Penicillium digitatum, Aspergillus niger, A.fumigatus, A. flavus, Rhizopus stolonifer and R.oryzae. Effiong and Sanni (2010) reported similar findings.

Table 1. Proximate chemical analysis of Coppens feed stored for 6 weeks (\% based on dry matter basis.).

\begin{tabular}{lllll}
\hline Parameters & Initial (WK zero) & Wk 2 & Wk 4 & Wk 6 \\
\hline Moisture & $6.86 \pm 0.12^{\mathrm{d}}$ & $8.16 \pm 0.03^{\mathrm{c}}$ & $15.42 \pm 0.02^{\mathrm{b}}$ & $18.42 \pm 0.02^{\mathrm{a}}$ \\
Ash & $7.69 \pm 0.01^{\mathrm{a}}$ & $6.93 \pm 0.01^{\mathrm{b}}$ & $6.00 \pm 0.02^{\mathrm{c}}$ & $5.94 \pm 0.02^{\mathrm{d}}$ \\
Lipid & $15.21 \pm 0.01^{\mathrm{b}}$ & $16.01 \pm 0.02^{\mathrm{a}}$ & $12.00 \pm 0.02^{\mathrm{a}}$ & $12.86 \pm 0.02^{\mathrm{c}}$ \\
Protein & $46.65 \pm 0.02^{\mathrm{a}}$ & $44.02 \pm 0.02^{\mathrm{c}}$ & $35.08 \pm 0.02^{\mathrm{d}}$ & $36.18 \pm 0.02^{\mathrm{d}}$ \\
Crude fibre & $3.20 \pm 0.01^{\mathrm{b}}$ & $2.86 \pm 0.02^{\mathrm{c}}$ & $3.68 \pm 0.03^{\mathrm{a}}$ & $2.43 \pm 0.02^{\mathrm{d}}$ \\
NFE* & $21.15 \pm 0.02^{\mathrm{d}}$ & $22.03 \pm 0.02^{\mathrm{c}}$ & $27.83 \pm 0.02^{\mathrm{a}}$ & $24.18 \pm 0.02^{\mathrm{b}}$ \\
\hline
\end{tabular}

*Nitrogen Free Extract. Data are expressed as mean of three replications. Means followed by the same letter within a column indicate no significant $(\mathrm{P}>0.05)$ difference. 
Table 2. Proximate chemical analysis of Vital feed stored for 6 weeks (\% based on dry matter basis).

\begin{tabular}{lllll}
\hline Parameters & Initial (WK zero) & Wk 2 & Wk 4 & Wk 6 \\
\hline Moisture & $11.57 \pm 0.02^{\mathrm{d}}$ & $12.76 \pm 0.02^{\mathrm{b}}$ & $17.46 \pm 0.02^{\mathrm{b}}$ & $20.46 \pm 0.02^{\mathrm{a}}$ \\
Ash & $10.33 \pm 0.02^{\mathrm{b}}$ & $10.70 \pm 0.02^{\mathrm{b}}$ & $9.93 \pm 0.02^{\mathrm{c}}$ & $8.90 \pm 0.02^{\mathrm{d}}$ \\
Lipid & $12.65 \pm 0.02^{\mathrm{a}}$ & $10.92 \pm 0.02^{\mathrm{b}}$ & $9.65 \pm 0.02^{\mathrm{c}}$ & $8.98 \pm 0.02^{\mathrm{d}}$ \\
Protein & $45.95 \pm 0.02^{\mathrm{a}}$ & $40.73 \pm 0.02^{\mathrm{b}}$ & $35.27 \pm 0.02^{\mathrm{d}}$ & $38.27 \pm 0.02^{\mathrm{d}}$ \\
Crude fibre & $2.27 \pm 0.02^{\mathrm{c}}$ & $2.88 \pm 0.02^{\mathrm{b}}$ & $2.94 \pm 0.02^{\mathrm{a}}$ & $2.61 \pm 0.02^{\mathrm{d}}$ \\
NFE* & $20.78 \pm 0.01^{\mathrm{d}}$ & $22.03 \pm 0.02^{\mathrm{b}}$ & $24.75 \pm 0.02^{\mathrm{a}}$ & $20.78 \pm 0.02^{\mathrm{c}}$ \\
\hline
\end{tabular}

*Nitrogen Free Extract. Data are expressed as means of three replicates. Means followed by the same letter within a column indicate no significant $(\mathrm{P}>0.05)$ difference.

Table 3. Anti-nutritional components in feed samples stored for 6 weeks at ambient temperature (mg/g).

\begin{tabular}{|c|c|c|c|c|c|c|c|c|}
\hline \multirow{3}{*}{$\begin{array}{l}\text { Anti-nutritional } \\
\text { components }\end{array}$} & \multicolumn{4}{|c|}{ Coppens feeds } & \multicolumn{4}{|c|}{ Vital feeds } \\
\hline & \multicolumn{4}{|c|}{ Time(Weeks) } & \multicolumn{4}{|c|}{ Time(weeks) } \\
\hline & 0 & 2 & 4 & 6 & 0 & 2 & 4 & 6 \\
\hline Oxalate & 0.72 & 0.81 & 0.90 & 1.08 & 0.63 & 1.08 & 1.08 & 1.17 \\
\hline Phytate & 7.41 & 8.24 & 9.89 & 11.54 & 7.41 & 9.06 & 12.36 & 13.18 \\
\hline Tannins & 0.78 & 0.79 & 0.79 & 1.15 & 0.62 & 1.06 & 1.14 & 1.213 \\
\hline
\end{tabular}

\section{Conclusion}

The findings of this experiment in line with those of the authors cited (Jones, 1987; Lim et al., 2008) indicate increase deterioration of feed quality with increase in storage period of feeds at ambient temperature. Therefore long storage of feeds should be discouraged to prevent quality loss. However additional research work involving environmental factors is recommended to further ascertain this assertion.

\section{Acknowledgement}

All authors of materials used directly or otherwise in the course of this experiment are hereby acknowledged including staff of Wet Laboratory, Federal College of Freshwater Fisheries Technology, New Bussa and Analytical Laboratories, Federal University of Technology, Akure all in Nigeria.

\section{References}

[1] AOAC (1990) Official methods of Analysis. Association Of Official Analytical Chemists, Inc, Washington DC, USA.

[2] Abowei, J.F.N and Tawari, C.C (2011) Some Basic principles of fish processing in Nigeria. Asian Journal of Agricultural Sciences 3(6): 437-452.

[3] Bautista, M. N., P.F; Subosa and R.L. Celia (1992) Effects of antioxidants on feed quality and growth of Penaeus monodon juvenile. J. Sci. Food Agric 1: $55-60$

[4] Brown, D.I (2009) Aflatoxins: Occurrence and Health risk. In: Plant Poisonous to livestock. Publication of Department of Animal Science, Cornell University.

[5] Chow, K.W (1980) Storage problems of feedstuff. Fish Feed Technology.Chap.13:pp216-244

[6] Cockerell,I Francis B.and Haliday, D.(1971) Changes in the nutritive value of concentrate feedstuffs during storage.
Proceedings of conference of Feed Resources and Improvement of Animal feeding methods in the CENTO Region countries, Tropical Products Institute, London,pp.181192.

[7] Effiong, B. N and Alatise, S.P (2009) Effect of mold infested feeds on the growth and survival of Heterobranchus longifils. Report and Opinion. 1(3) pp 9-14.

[8] Effiong, B.N and Sanni, A (2010) Antifungal properties and phytochemical screening of crude extract of Lemna pauciscoststa (Helgelm) against fish feed spoilage fungi. Life Science Journal 7 (3):1-4.

[9] FAO/IAEA (2000) Quantification of tanins in tree foliage. A laboratory manual for the FAO/IAEA Co-ordinated research project on 'use of nuclear and related techniques to develop simple tannin assays for predicting and improving the safety and efficiency of feeding ruminants on tanniferous tree foliage'. Available at:http://www.naweb.iaea.org/nafa/aph/public/pubd31022manual-tannin.pdf.

[10] Francis, G; Makkar, H.P.S and Becker, K (2001) Antinutritional factors present in plant derived alternate fish ingredients and their effects in fish.Aquaculture.Vol.199 (3-4) pp197-227

[11] Friedman, L; and Shibko, S.I (1972) Non-nutrient components of the diet in fish nutrition; I.E. Halver, Ed. Academic press, New York Pp 182-255

[12] Hamilton, P.B (1989) The chemistry of rancidity in foods In: Rancidity in foods $\left(2^{\text {nd }} E d\right.$.) Allen, J.C and Hamilton, R. J. Elsevier Applied science. London and New York.

[13] Jones, F. (1987) Controlling mould growth in feeds. Feeds International.8:20-29.

[14] Lim, H.A;W.K,Ng;S.L Lim and C.O Ibrahim(2008) Contamination of palm kernel meal with Aspergillus flavus affects its nutritive value in pelleted feed feed for Tilapia, Oreochromis mossambicus. Aquaculture Research. Vol 32.Issue11:895-905

[15] Makkar, H. P.S and Becker, K (1999a) Plants toxins and detoxification methods to improve feed quality of tropical seeds: Review. Asian - Aus .J. Animal Science. 12(3) 467-480 
[16] Makkar, H. P.S and Becker, K (1999a) Nutritional studies on rats and fish (Carp Cyprinus carpio) fed diets containing unheated and heated Jatropha curcas meal of a non- toxic provenance. Plants food Hum. Nutri. 53: 183-192

[17] Nwabueze, A.A and R.O Nwabueze (2011) Microbial flora of fish feeds sold in Asaba, Southern Nigeria. American Journal of Experimental Agriculture 1(2):27-32

[18] Nwachukwu, C.O (1988) Microbiology of pepper (C.annum) and the efficacy of some local methods of preservation. M.Sc Thesis. Biological Sciences. Unillorin.

[19] Oloke, J.K; Komolafe, D.O and Erhrun, W.O (1988) The antimicrobial and antifungal activities of certain components of Aframonium meleguets fruits.Fitoterapia.59 (5)384-388.

[20] Ramezanzadeh, F.M., R.M. Rao; M. Windhauser, W. Prinyawwatkul; R.Tully and W.E Marshall (1999) Prevention of hydrolytic rancidity in rice bran during storage. J. Agric. Food chemistry; 47: 3050-3052.
[21] Russo, J. R; Yanong, R.P.E (2006) Molds in fish feeds and aflatoxicosis. Fact sheet FA-95 Department of fisheries and Aquatic sciences (SFRC) Florida. Cooperative Extension Inst. Food Agric.Sci. University Florida

[22] Ruiz, J.A; A.M Perez-Vendreli and E.Estere- Garcia (2000) Effect of deitary iron and copper on performance and oxidative stability in broiler leg meat. Br. Poult. Sci. 41; 163167

[23] Sander, T.A (1989) Nutritional Aspect of rancidity in: Rancidity in food ( $2^{\text {nd }}$ Ed.) Allen, I.C and Hamilton. R. J. Elsevier Applied Science. London and New York.

[24] Van den Berghe; C.H; P.O. Abouagniou and E.K. Deka (1990) The effect of antioxidant and mold inhibitor on feed quality and the performance of broilers under tropical conditions. Trop.Sci.; 30: 5-13 